\title{
PROPERTIES OF LOW-PH CEMENT GROUT AS A SEALING MATERIAL FOR THE GEOLOGICAL DISPOSAL OF RADIOACTIVE WASTE
}

\author{
JIN-SEOP KIM ${ }^{* 1}$, S. KWON ${ }^{1}$, JONG-WON CHOI ${ }^{1}$, and GYE-CHUN CHO ${ }^{2}$ \\ ${ }^{1}$ Korea Atomic Energy Research Institute (KAERI) \\ Daejeon 305-353, Korea \\ ${ }^{2}$ Korea Advanced Institute of Science and Technology (KAIST) \\ Daejeon 305-701, Korea \\ *Corresponding author. E-mail : kverity@kaeri.re.kr
}

Received December 23, 2010

Accepted for Publication April 09, 2011

The current solution to the problem of using cementitious material for sealing purposes in a final radioactive waste repository is to develop a low-pH cement grout. In this study, the material properties of a low-pH cement grout based on a recipe used at ONKALO are investigated by considering such factors as $\mathrm{pH}$ variation, compressive strength, dynamic modulus, and hydraulic conductivity by using silica fume and micro-cement. From the $\mathrm{pH}$ measurements of the hardened cement grout, the required $\mathrm{pH}(<\mathrm{pH} 11)$ is obtained after 130 days of curing. Although the engineering properties of the low-pH cement grout used in this study are inferior to those of conventional high-pH cement grout, the utilization of silica fume and micro-cement effectively meets the long-term environmental and durability requirements for cement grout in a radioactive waste repository.

KEYWORDS : Low-pH Cement Grout, Silica Fume, Radioactive Waste Disposal, Compressive Strength, Dynamic Shear Modulus, Hydraulic Conductivity

\section{INTRODUCTION}

The OECD NEA (Nuclear Energy Agency) anticipates that by 2050 the amount of nuclear-generated electricity worldwide will increase by a minimum of 1.6 times and a maximum of 3.9 times its 2008 value of 372 GWe [1]. At the same time, the amount of radioactive waste that will be produced is expected to increase substantially. High-level radioactive waste is usually derived from the burning of uranium fuel in a nuclear reactor. Fission products and transuranic components such as spent fuel can be included in the definition of high-level waste. Although various radioactive waste disposal concepts, including deep-seabed disposal, disposal in the polar ice sheets, and rocketing of the waste into space, have been investigated, deep geological disposal is generally considered to be the best option to deal with high-level radioactive wastes [2].

In South Korea, a total of twenty nuclear reactors are in operation; the cumulative amount of spent fuel is estimated to be 10,490 MTU (2009). The full capacity of the country's storage is anticipated to be saturated around 2016 , and choosing a long-term disposal policy is an urgent matter. However, a national strategy for spent fuel management has not yet been set down, and high-level waste (HLW) such as spent fuel will have to be stored atreactor (AR) by re-racking or in interim storage vessels such as dry storage casks until 2016, in accordance with the decision of $256^{\text {th }}$ Korea Atomic Energy Commission (2004).

Even if the decision on what kind of disposal policy to adopt in Korea is answered in the near future, the use of cementitious materials is inevitable at least to deal with the constraints of water ingress, access tunnel floors, plugging of backfill, and sealing of tunnels from water flowing into a HLW repository. Regular/conventional cement (in general of high-pH) can accelerate the release of uranium; increase the mobility of uranium, fission products, and actinides. It can also change the solubility of bentonite, which aggravates the function of buffer materials. To minimize the environmental impact and influence of cementitious materials, the development of optimized cement is indispensable; research into field applications for and long-term performance of such materials is needed. As part of an effort to optimize the properties of cementitious materials, studies related to 
the development and validation of low-pH grout have been actively carried out in both the laboratory and the field $[3,4,5,6]$. For example, low-pH grout has been studied since 2002 in a joint project of the Swedish Nuclear Fuel and Waste Management Company (SKB), the Nuclear Waste Management Expert of Finland (POSIVA) and the Nuclear Waste Management Organization of Japan (NUMO) [5]. Based on those studies, the $\mathrm{pH}$ criterion has been specified and the properties of a low-pH grout mix have been optimized [7]. Additionally, the functional requirements for low-pH grout were established by Kronlöf (2005). SKB and POSIVA have defined a $\mathrm{pH}$ limit of $<11$ for low-pH cement grout leachates. To meet this $\mathrm{pH}$ requirement, blending agents should comprise at least $40 \mathrm{wt} \%$ of dry materials and the $\mathrm{Ca} / \mathrm{Si}$ ratio, primarily formed as calcium silicate hydrate $(\mathrm{CSH})$ gel, should be under 0.8. Silica fume (SF) as a blending agent is considered to be the most promising agent for low-pH grouts of repositories [8].

The aim of this study is to evaluate the comprehensive material properties (e.g., the $\mathrm{pH}$ variation of the hardened grout, the compressive strength, the dynamic modulus, and the hydraulic conductivity) of a low-pH grout made with silica fume and micro-cement, based on the recipe suggested by the underground characterization facility in Finland (ONKALO). In addition to the design mixture proposed by POSIVA, four more grout recipes were investigated to identify the effect of SF contents on the $\mathrm{pH}$ variation and the strength gain for the cement grout resulting from fixing the water-to-binder ratio $(\mathrm{w} / \mathrm{b}=0.92)$.

\section{DESIGN REQUIREMENTS OF LOW-PH GROUT}

The hydration of cement paste initially shows a $\mathrm{pH}$ greater than 13 because of the dissolution of sodium and potassium hydroxides. Of the hydrate phases that are brought into contact with water, the highest $\mathrm{pH}$ comes from portlandite, which shows a $\mathrm{pH}$ of around 12.5; the next comes from calcium silicate hydrate [8]. A basic concept to develop low-pH cement grout is to decrease the $\mathrm{pH}$ value by replacing a portion of the cement in use with pozzolanic materials. Of the various candidates, SF is regarded as the most effective at lowering the $\mathrm{pH}$ of cement for both functional requirements and environmental safety concerns.

The maximum allowable $\mathrm{pH}$ limit for cement materials is under $\mathrm{pH} 11$ [5]. However, the theoretical base for a $\mathrm{pH}$ limit has not yet been made clear. Only a few guidelines have been provided about the dissolution of montmorillonite, which is a main component of bentonite, under high alkaline pore water conditions. The reaction between hydroxyl groups in cement leachate and bentonite gives a significant release of silicon beyond $\mathrm{pH} 10$, while the relatively stable behavior of $\mathrm{SiO}_{2}$ below $\mathrm{pH} 10$ has been demonstrated. The chemical reaction of montmorillonite changes with $\mathrm{pH}$ variation as follows [9]:

$$
\begin{aligned}
\mathrm{pH}<10: & \mathrm{Na}_{0.33} \mathrm{Mg}_{0.33} \mathrm{Al}_{1.67} \mathrm{Si}_{4} \mathrm{O}_{10}(\mathrm{OH})_{2}+2 \mathrm{H}_{2} \mathrm{O} \Rightarrow \\
& 0.33 \mathrm{Na}^{+}+0.33 \mathrm{Mg}^{2+}+1.67 \mathrm{Al}^{3+}+4 \mathrm{SiO}_{2(\mathrm{aq})}+ \\
& 6 \mathrm{OH}^{-}
\end{aligned}
$$

$$
\begin{aligned}
& 10<\mathrm{pH}<13: \mathrm{Na}_{0.33} \mathrm{Mg}_{0.33} \mathrm{Al}_{1.67} \mathrm{Si}_{4} \mathrm{O}_{10}(\mathrm{OH})_{2}+4.68 \mathrm{OH}^{-}+ \\
& 2 \mathrm{H}_{2} \mathrm{O} \Rightarrow 0.33 \mathrm{Na}^{+}+0.33 \mathrm{Mg}^{2+}+1.67 \mathrm{Al} \\
& (\mathrm{OH})_{4}^{-}+4 \mathrm{HSiO}_{3}
\end{aligned}
$$

$$
\begin{aligned}
& \mathrm{pH}>13: \mathrm{Na}_{0.33} \mathrm{Mg}_{0.33} \mathrm{Al}_{1.67} \mathrm{Si}_{4} \mathrm{O}_{10}(\mathrm{OH})_{2}+8.68 \mathrm{OH}^{-}+ \\
& 2 \mathrm{H}_{2} \mathrm{O} \Rightarrow 0.33 \mathrm{Na}^{+}+0.33 \mathrm{Mg}^{2+}+1.67 \mathrm{Al}(\mathrm{OH})_{4}{ }^{-} \\
&+4 \mathrm{H}_{2} \mathrm{SiO}_{4}{ }^{2-}
\end{aligned}
$$

The main requirement for cement grout is a $\mathrm{pH}$ lower than 11; this works as a guideline for other functional requirements in laboratory determinations. Design requirements for low-pH grout have been suggested based on experimental tests in the laboratory, the results of which are summarized in Table 1. Because all desired properties (e.g., stability and durability of grout) cannot be directly measured quantitatively, the property requirements are still under discussion and are subject to verification by worldwide research bodies. In addition to compressive strength, dynamic modulus, and hydraulic conductivity, which are the primary parameters for durability studies of cementitious materials, the $\mathrm{pH}$ measurement is selected for the compatibility assessment in this study.

Table 1. Requirements used for Development of Low-pH Grout in the Laboratory [3].

\begin{tabular}{c|l|l}
\hline Order of Importance & \multicolumn{1}{|c}{ Property } & Requirement \\
\hline & & \\
& $\mathrm{pH}$ & $\leq 11$ \\
Required & ${\text { Penetration ability } b_{\text {min }}}$ & $\leq 80 \mu \mathrm{M}$ \\
Properties & Penetration ability $\mathrm{b}_{\text {crit }}$ & $\leq 120 \mu \mathrm{M}$ \\
& & \\
& & \\
& & $\leq 50 \mathrm{MPAS}$ \\
& Viscosity & $\leq 10 \%$ \\
& Bleed & $\geq 60 \mathrm{MIN}$ \\
Desired & Workability time & $\geq 500 \mathrm{PA}$ \\
& Shear strength & $\leq 5 \mathrm{PA}$ \\
& Yield value & $\geq 4 \mathrm{MPA}$ \\
& Compressive strength & \\
\hline
\end{tabular}




\section{EXPERIMENTAL PROGRAM}

\subsection{Materials used}

Two different grout mixtures are considered in this study. The mixture proportions of low-pH cement grout are based on the results of ONKALO, which show stable and recommendable performance in both laboratory and field tests [7]. The mixtures used are summarized in Table 2. In particular, additional mixtures are tested to explore the effect of $\mathrm{SF}$ on the $\mathrm{pH}$ variation and the compressive strength development of the grout (LP2$10 \%, 20 \%, 30 \%$ and $40 \%$ ), where percentages in LP2 indicate the ratio of SF to total binder (SF/b) under a fixed water to total binder ratio of 0.92 . In Table 2, LP2$40 \%$ is one of the other optimized low-pH grout recipes under investigation in Finland [7].

The cement used for grout specimens is made of micro-cement (Mycem8000). Its fineness is $8,250 \mathrm{~cm}^{2} / \mathrm{g}$; its average diameter falls into the range of 4 to $6 \mu \mathrm{m}$ and D90 < $13 \mu \mathrm{m}$; and its main chemical components are $\mathrm{SiO}_{2}(27.8 \%), \mathrm{CaO}$ plus $\mathrm{MgO}(56.1 \%), \mathrm{Al}_{2} \mathrm{O}_{3}$ plus $\mathrm{Fe}_{2} \mathrm{O}_{3}$ (12.9\%), $\mathrm{SO}_{3}(2.1 \%)$, and $\mathrm{Na}_{2} \mathrm{O}$ plus $\mathrm{K}_{2} \mathrm{O}(0.6 \%)$. As a main admixture to lower the high-pH of cement, the silica fume Elkem Microsilica $940 \mathrm{U}$ was selected. Its specific surface area is 15,000 to $30,000 \mathrm{~m}^{2} / \mathrm{kg}$, and its average particle size is below $0.15 \mu \mathrm{m}$. The use of high amounts of SF causes a high water demand with the mixture due to the finer grain size and gelation of the SF when it is brought into contact with the high-pH plume. This water demand can be overcome by adding a superplasticizer. Thus, ROADCON-SP, which is one of the naphthalene sulfonated-formaldehyde copolymers, is used to reduce the water content in grout mixtures: its specific gravity is $1.02^{\circ} \pm 0.02\left(20^{\circ} \mathrm{C}\right)$, and its $\mathrm{pH}$ is $7 \pm 1$ $\left(20^{\circ} \mathrm{C}\right)$.
The micro-cement was added to the water. Then SF and superplasticizer were added and stirred by using a mortar mixer for three minutes. Two types of specimens were made: one was of a cubic shape $(5 \times 5 \times 5 \mathrm{~cm})$, and was used for compressive strength tests; the other was cylindrical $(5 \times 10 \mathrm{~cm})$, and was used for dynamic tests. All of the specimens were cured in a water bath with a constant temperature of $23^{\circ} \mathrm{C}$ until the day of interest.

\subsection{Experimental Procedures}

1) $\mathrm{pH}$ measurement of hardened grout A standard method for $\mathrm{pH}$ measurement of hardened concrete has yet to be established. Various researchers and groups have selected their own methods within reasonable considerations $[10,11,12]$. One reliable method, the measurement of $\mathrm{pH}$ in powdered cement paste-water slurries, was selected for this study $[13,14]$. To measure the $\mathrm{pH}$ value of hardened cement grout samples, hardened specimens were ground to make the particle size of the grout smaller than $75 \mu \mathrm{m}$. Then, $10 \mathrm{~g}$ of ground specimen was sampled and mixed with $10 \mathrm{ml}$ of distilled water for three minutes using a stirrer. Then, solutions were extracted by filtering out the mixtures with a membrane filter paper with an effective size of $45 \mu \mathrm{m}$.

2) Uniaxial compressive strength Cube specimens with dimensions of $5 \times 5 \times 5 \mathrm{~cm}$ were used to determine the compressive strength of the corresponding curing age by following ASTM C109 [15].

3) Dynamic properties using FFRC

The dynamic properties of cementitious materials are very useful in fatigue, creep, and durability studies for identifying the onset of degradation. Dynamic testing

Table 2. Grout Mixture Designs.

\begin{tabular}{c|c|c|c|c|c|c}
\hline & $\begin{array}{c}\text { Standard } \\
\text { (high-pH) } \\
\text { grout } \\
\text { Component }\left[\mathrm{kg} / \mathrm{m}^{3}\right]\end{array}$ & $\begin{array}{c}\text { Low-pH } \\
\text { grout } \\
\text { mixture } \\
\text { (HP) }[7]\end{array}$ & LP2-10\% & LP2-20\% & LP2-30\% & LP2-40\% [7] \\
\hline Water $\left[\mathrm{kg} / \mathrm{m}^{3}\right]$ & 716 & 789 & 709 & 709 & 709 & 709 \\
\hline Micro-cement $\left[\mathrm{kg} / \mathrm{m}^{3}\right]$ & 882 & 328 & 691 & 614 & 538 & 230 \\
\hline Silica fume $\left[\mathrm{kg} / \mathrm{m}^{3}\right]$ & 0 & 226 & 77 & 154 & 12 & 313 \\
\hline Superplasticizer $\left[\mathrm{kg} / \mathrm{m}^{3}\right]$ & 7 & 9 & 12 & 0.92 & 0.92 & 0.92 \\
\hline Water-to-binder ratio & 0.81 & 1.42 & 0.92 & 12 \\
\hline
\end{tabular}




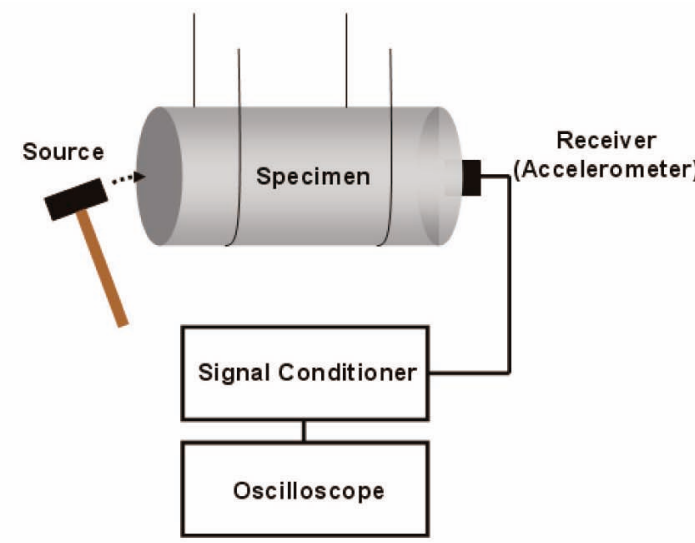

(a)

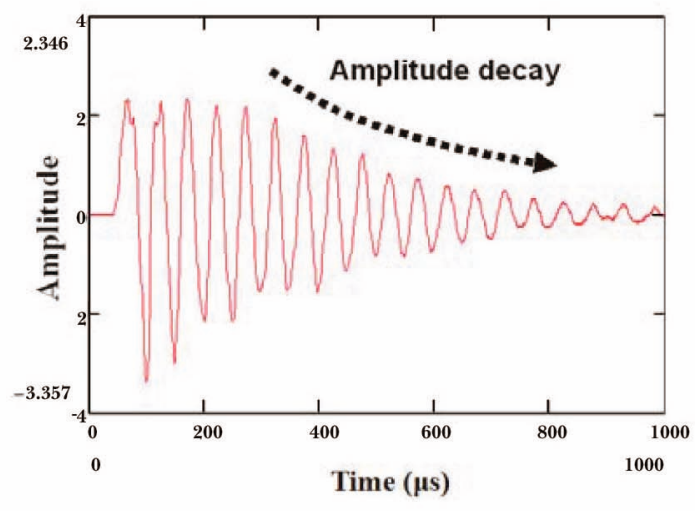

(b)

Fig. 1. Experimental Method for Measurement of Dynamic Properties of Cement Grout: (a) FFRC Test set-up and (b) Typical Result - Data Reduction.

is advantageous not only for its non-destructive manner but also for obtaining intrinsic material properties because dynamic properties are from the small strain range far below the elastic limit and are directly related to the internal structure [16].

In this study, the dynamic properties of cement grout material are determined by the free-free resonant column (FFRC) method (KS F2437) [17], which is similar to the method in ASTM C215 [18]. The resonant column test is the most commonly used laboratory test for measuring low strain properties of concrete such as dynamic modulus and damping characteristics. The experimental setup for this process, and the typical results, are shown in Fig. 1. Grout specimens aged for 30 days which were $50 \mathrm{~mm}$ in diameter and $100 \mathrm{~mm}$ in length were used to measure the dynamic properties.

Based on the information on the frequency corresponding to the peak amplitude, which is the first mode resonant frequency of a specimen, $V_{\text {rod }}$ is calculated from the wavelength multiplied by 2 . Given that Poisson's ratio is known (herein, $v=0.28 \sim 0.31$ ), wave velocities and categories of dynamic modulus such as elastic, shear, and constraint modulus can be subsequently obtained as

$$
\begin{gathered}
V_{\text {rod }}=\sqrt{\frac{E}{\rho}}, \\
V_{P}=\sqrt{\frac{(1-v)}{(1+v)(1-2 v)} \frac{E}{\rho}}=\sqrt{\frac{M}{\rho}}, \\
V_{S}=\sqrt{\frac{1}{2(1+v)} \frac{E}{\rho}}=\sqrt{\frac{G}{\rho}},
\end{gathered}
$$

where $E$ is the elastic modulus of a specimen $(\mathrm{GPa})$, $V_{\text {rod }}$ is the rod wave velocity $(\mathrm{m} / \mathrm{s}), M$ is the constraint modulus $(\mathrm{GPa}), V_{\mathrm{p}}$ is the $\mathrm{P}$ wave velocity $(\mathrm{m} / \mathrm{s}), V_{\mathrm{s}}$ is the $\mathrm{S}$ wave velocity $(\mathrm{m} / \mathrm{s}), \rho$ is the density of a specimen $\left(\mathrm{kg} / \mathrm{m}^{3}\right)$, and $v$ is Poisson's ratio.

4) Hydraulic conductivity

The hydraulic conductivity of cementitious material, which limits the mass transport of corrosive agents, is closely related to the long-term durability of hardened cement. The lower the hydraulic conductivity is, the higher the resistance to the deterioration process. However, the required value for hydraulic conductivity has not yet been clearly identified, and it is only roughly ensured by setting the requirements for the uniaxial compressive strength of a grout.

The steady flow method is applied to measure the water permeability of cement grout [19]. The testing apparatus is partly modified to increase water tightness in a housing cell. Hydraulic conductivity is calculated by measuring the cumulative amount of de-ionized water passing through the sample and by using Darcy's law as follows:

$$
K=\frac{\rho L g Q}{P A}
$$

where $K$ is the hydraulic conductivity $(\mathrm{m} / \mathrm{s}), L$ is the sample thickness (m), $\rho$ is density of water $\left(\mathrm{kg} / \mathrm{m}^{3}\right), g$ is acceleration due to gravity $\left(\mathrm{m} / \mathrm{s}^{2}\right), Q$ is the effluent steady-state volumetric flow $\left(\mathrm{m}^{3} / \mathrm{s}\right), \Delta \mathrm{P}$ is the pressure gradient $(\mathrm{Pa})$, and $A$ is the cross-sectional area of the specimen perpendicular to the direction of flow $\left(\mathrm{m}^{2}\right)$. During the measurement of hydraulic conductivity, a pressure of $1,060 \mathrm{kPa}$ was applied by using compressed 


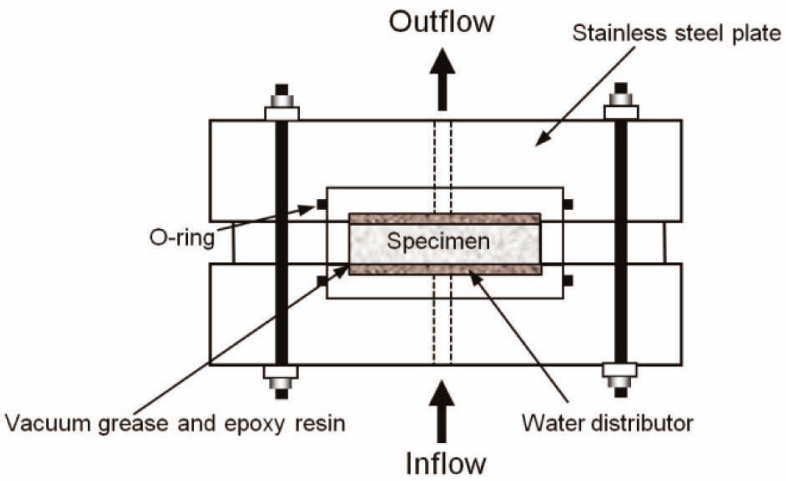

(a)

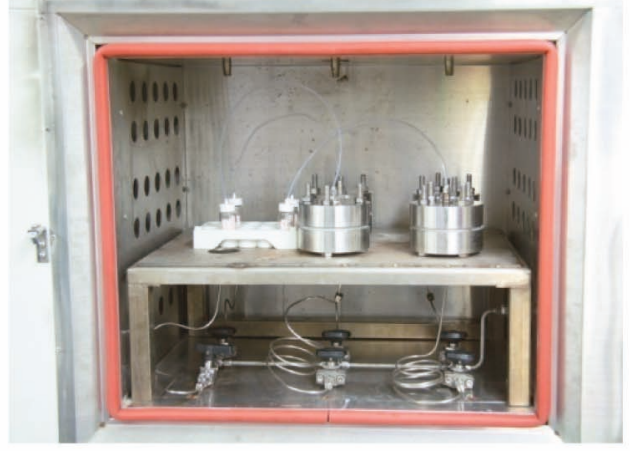

(b)

Fig. 2. Schematic Drawing and Photographic Image of a Hydraulic Conductivity Housing cell (a) and Test Apparatus (b).

nitrogen gas at a temperature of $23^{\circ} \mathrm{C}$. The thickness of the grout sample was $\mathrm{T}=10 \mathrm{~mm}$, and its diameter was $\phi=50 \mathrm{~mm}$. All the specimens were tested at the age of 90 days. A schematic drawing and a photographic image of the hydraulic conductivity housing cell and the test apparatus are shown in Fig. 2.

\section{RESULTS AND DISCUSSION}

\section{1 pH of Hardened Cement Grout}

Figure 3 shows the $\mathrm{pH}$ variation of hardened cement grout specimens versus curing time. At the initial stage of curing, the $\mathrm{pH}$ values of high-pH grout (HP) and low$\mathrm{pH}$ grout (LP) are similar at about $\mathrm{pH}$ 12.9. In the case of $\mathrm{HP}$, the $\mathrm{pH}$ decreases and converges to $\mathrm{pH} 12.5$ after about 30 days. The initial $\mathrm{pH}$ of ordinary Portland cement (OPC) paste solution is typically around $\mathrm{pH} 13$. The hyperalkaline condition results from the dissolution of sodium and potassium hydroxides which do not bind to any early hydrate phases and thus accumulate in the pore solution as alkali hydroxide [8]. Subsequently, the $\mathrm{pH}$ of OPC paste is expected to decrease to about $\mathrm{pH}$ 12.5. This stage is mainly influenced by the dissolution of the calcium hydroxides. The calcium hydroxides dissolve later than sodium and potassium hydroxides because the dissolution of calcium compounds in the pore solution is derived from the solid phase of hydrated cement [13]. The $\mathrm{pH}$ variation of HP in Fig. 3 corresponds to that of typical OPC paste.

However, the LP shows a continuous decreasing pattern in $\mathrm{pH}$, remaining below $\mathrm{pH} 11$ after 130 days, and finally converging. A $40 \%$ replacement of cement with $\mathrm{SF}(\mathrm{SF} / \mathrm{b})$ is effective in decreasing the $\mathrm{pH}$ of the grout by changing the composition of calcium silicate hydrate

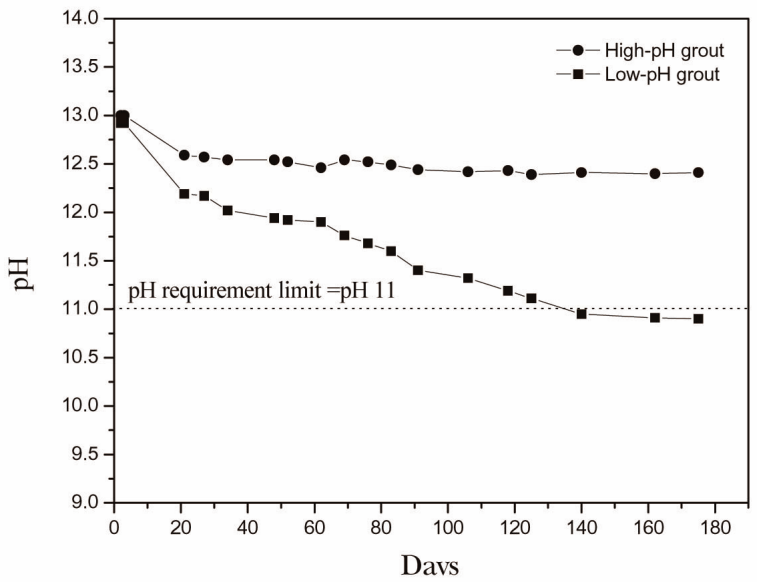

Fig. 3. Measurements of $\mathrm{pH}$ Variations in High- and Low-pH Cement Grouts

(CSH). CSH gels are amorphous or semi-crystalline and are characterized by a variable composition with a wide range of $\mathrm{Ca} / \mathrm{Si}$ ratios, which is usually affected by cement type, curing time, temperature, water/cement ratio, and so on. The $\mathrm{Ca} / \mathrm{Si}$ ratio of $\mathrm{CSH}$ from freshly hydrated Portland cement is about 1.5 [20]. Degradation of cementitious material tends to lower the $\mathrm{Ca} / \mathrm{Si}$ ratio because of the incongruent dissolution between $\mathrm{Ca}$ and $\mathrm{Si}$ (preferential release of Ca over $\mathrm{Si}$ ) [21].

Figure 4 shows the effects of only SF content on the $\mathrm{pH}$ in cement grout apart from the optimized low-pH grout recipes, in which the water-to-binder ratio is maintained at 0.92. Apparently, the higher SF content gives a lower $\mathrm{pH}$ value to the grout. Meanwhile, all the 


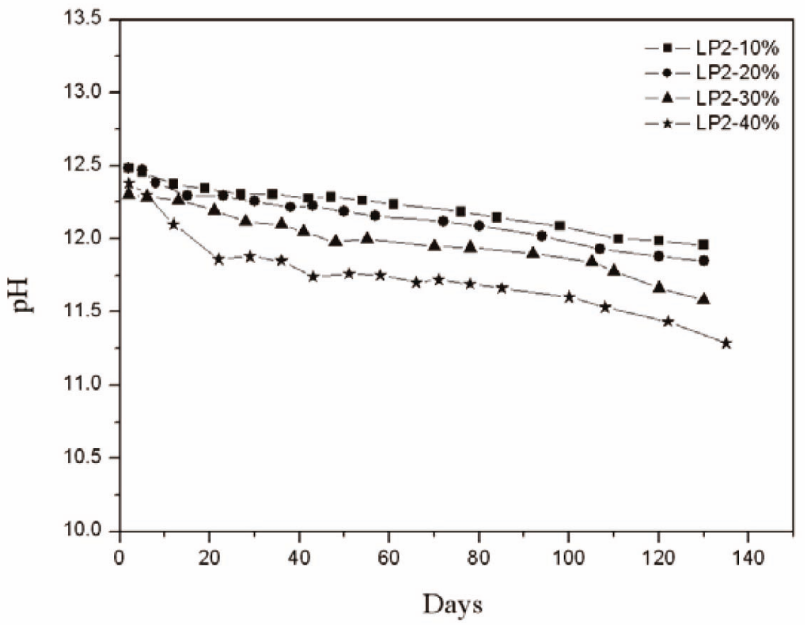

Fig. 4. Effects of Silica Fume Contents on the $\mathrm{pH}$ of Cement Grout (LP2)

$\mathrm{pH}$ values were above the criteria (requirement limit) within the period of measurement (i.e., 130 days) and hardly showed converging patterns. This is attributed to the fact that the full hydration of cementitious materials usually requires a long time, more than 90 days [22]. Low $\mathrm{pH}$ cement shows slower hydration than Portland cement [23]. It can be anticipated that grout with a higher $\mathrm{SF}$ content tends to decrease $\mathrm{pH}$ more with time than those with lower SF content.

\subsection{Compressive Strength}

The uniaxial compressive strengths of low- and high$\mathrm{pH}$ specimens are shown in Fig. 5. The compressive strength of the grout mixed with a large amount of SF (i.e., LP; $40 \%$ as of $\mathrm{SF} / \mathrm{b}$ ) is much lower than that of those without SF (i.e., HP). The strength increase of LP is also less than the strength increase of HP between 7 and 28 days. The compressive strengths of HP and LP specimens at 28 days are 31.6 and $6.3 \mathrm{MPa}$, respectively. The main reason for such a strength discrepancy is thought to be the different $\mathrm{w} / \mathrm{b}$ ratios and setting times of HP and LP. Of concern in a waste repository is the delay of the setting time, usually derived from the difference in hydration of SF compared to cement. When it comes to the requirement for compressive strength of LP, the result in this study still satisfies the design criteria ( $\geq 4 \mathrm{MPa}$ at 28 days, as shown in Table 1 ).

Generally, SF is used to increase the ultimate strength of concrete due to both physical (microfiller action) and chemical (pozzolanic activity) effects [24]. It is well known that the desirable SF content is between $5 \%$ and $15 \%$ of $\mathrm{SF} / \mathrm{b}$, where $\mathrm{w} / \mathrm{b}$ is recommended to be below 0.3 [20]. Beyond $15 \%$ SF content, the compressive strength

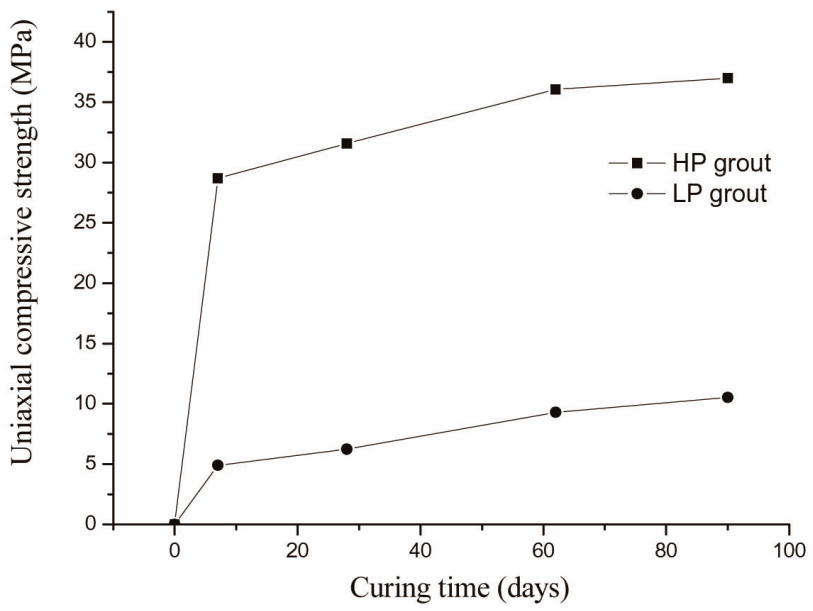

Fig. 5. Comparison of Compressive Strengths in High- and Low-pH Cement Grouts

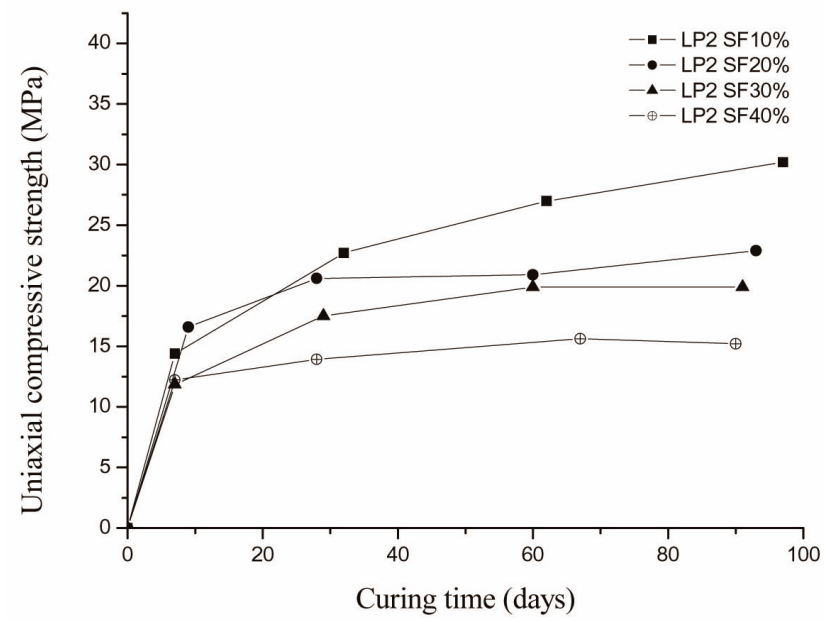

Fig. 6. Effect of Silica Fume on the Compressive Strength of Grout where w/b ratio is Fixed at 0.92 .

of concrete tends to decrease [24]. It should be kept clear, however, that nearly all of the previous studies using SF have focused on high-strength or high-performance concrete, in which the $\mathrm{w} / \mathrm{b}$ ratio is very low $(<0.5)$; such a ratio is not possible for low-pH cement grout, in which the effective $\mathrm{w} / \mathrm{b}$ ratio is generally above 1.0 .

It is clear from the data presented in Fig. 6 that the SF content tends to decrease the strength gain with curing time and does not affect the strength gain rate beyond $10 \%$ SF content, at least within these test conditions. For more accurate investigation of the effects of SF content for a given $w / b$, the differences in reactive and binding 
Table 3. FFRC Test Results for Low- and High-pH Grouts.

\begin{tabular}{|c|c|c|c|c|}
\hline \multirow{2}{*}{ Parameter } & \multicolumn{2}{|c|}{ HP } & \multicolumn{2}{|c|}{ LP } \\
\hline & Saturated & Dry & Saturated & Dry \\
\hline Rod wave velocity, $V_{R}[\mathrm{~m} / \mathrm{s}]$ & 2707 & 2064 & 1793 & 1387 \\
\hline Young's modulus, E [GPa] & 11.9 & 6.7 & 4.4 & 2.3 \\
\hline P-wave velocity, $\mathrm{V}_{\mathrm{p}}[\mathrm{m} / \mathrm{s}]$ & 3026 & 2307 & 2145 & 1660 \\
\hline S-wave velocity, $\mathrm{V}_{\mathrm{s}}[\mathrm{m} / \mathrm{s}]$ & 1699 & 1295 & 1104 & 853 \\
\hline Constraint modulus, $\mathrm{M}$ [GPa] & 14.9 & 8.4 & 6.3 & 3.3 \\
\hline Shear modulus, G [GPa] & 4.7 & 2.6 & 1.6 & 0.9 \\
\hline Damping ratio & 0.023 & 0.027 & 0.024 & 0.044 \\
\hline Density, $\rho\left[\mathrm{kg} / \mathrm{m}^{3}\right]$ & 1,627 & 1,580 & 1,372 & 1,190 \\
\hline Poisson's ratio, $v$ & \multicolumn{2}{|c|}{0.27} & \multicolumn{2}{|c|}{0.32} \\
\hline
\end{tabular}

capacity between SF and cement should be taken into account. Compared to cement, the efficiency factor (kvalue) of SF is usually taken to be 2 , because SF has a stronger reactive and binding capacity than cement [25]. For example, the w/b of 1.42 shown in Table 2 changes to an effective $w / b$ of 1.0. This information can be used to estimate the long-term durability performance, but the $\mathrm{k}$-value is still under discussion [26].

\subsection{Dynamic Properties}

The measured wave characteristics and dynamic moduli are shown in Fig. 7 and are summarized in Table 3. The velocities of elastic waves through a specimen of cement grout saturated with water, which can simulate the real condition of grout in the field, are faster than those under dry conditions. Additionally, it should be noted that wave velocities in high-pH grouts are also faster than those in low-pH grouts. When it comes to damping ratios, those of HP scarcely seem to be affected by the degree of saturation as shown in Table 3. However, in the case of LP, the measured damping ratios for dry specimens increase about two times compared to those of saturated specimens.

Damping of dry specimens was usually less than in wet condition [27]. Water is expected to act as a viscous damping mechanism in the free-free vibration; thus, the presence of water tends to increase the hydraulic damping which dissipates energy mostly through viscous shear

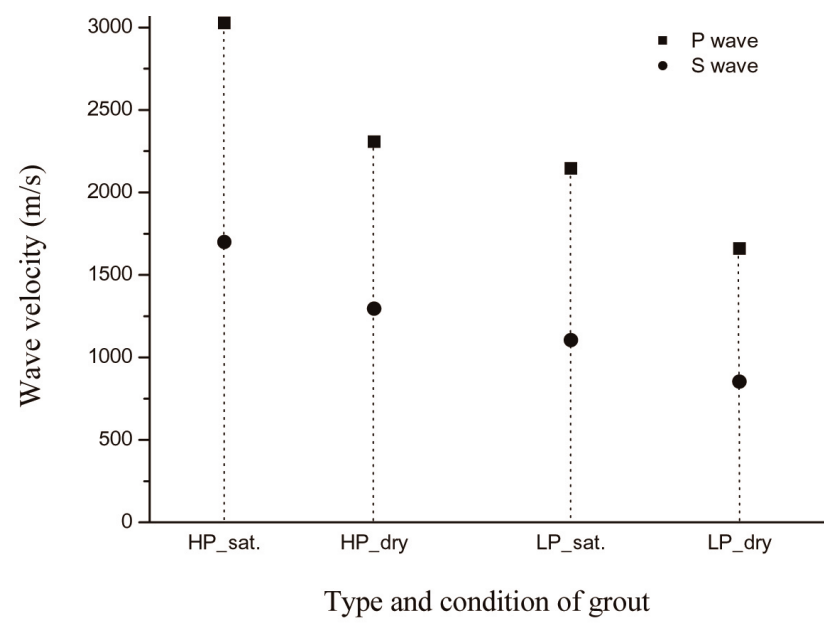

Fig. 7. Changes in Elastic Wave Velocity According to the Degree of Saturation in Cement Grout

[28]. The damping ratios in this study, however, show different patterns. The $\mathrm{w} / \mathrm{b}$ ratio of $\mathrm{HP}$ is relatively high due to the use of micro-cement and the grout characteristics compared to ordinary concrete. While LP needs a still higher $\mathrm{w} / \mathrm{b}$ ratio because of the additional use of SF (Table 3). The specimens with high $\mathrm{w} / \mathrm{b}$ ratios undergo a lot of autogenous shrinkage with hydration and drying 
shrinkage when they are drying. The shrinkage would produce micro-cracks inside the grout specimen, which are expected to be the primary cause for the increased damping ratio of dry specimens (no less than saturated specimens). Because more shrinking cracks are produced in a dry LP specimen than in a dry HP, the measured damping ratio is higher.

The dynamic shear modulus of dried LP is $0.9 \mathrm{GPa}$, and it changes to $1.6 \mathrm{GPa}$ under saturated conditions. These data are attributable to the fact that the wave velocity in a gel pore or a capillary pore saturated with water is faster than through pore spaces or fractures in cement grout. Also, there should be micro-cracks inside the grout specimen because of a large amount of shrinkage, which is a potential concern, especially in LP with a high $\mathrm{w} / \mathrm{b}$ ratio. The wave propagation is primarily dependent on the density or porosity of the specimen.

After the installation of spent fuel into a nuclear waste repository, generally, more than 100 years of dynamic monitoring and facility operation should follow before system closure for permanent disposal. From this point of view, these dynamic properties of cement grout can be used as valuable input data for the dynamic analysis of an engineered barrier system or a near-field rock mass in a nuclear waste repository.

\subsection{Hydraulic Conductivity}

Test results on the hydraulic conductivity of LP and HP using the steady-state flow method are shown in Fig. 8 , in which only the data in a linear relation between the cumulative volume of penetrated water and time are presented. The hydraulic conductivity of LP is $4.3 \times 10^{-13}$ $\mathrm{m} / \mathrm{sec}$, which is slightly lower than the value typically observed for intact granite (which is on the order of $1 \times 10^{-12}$

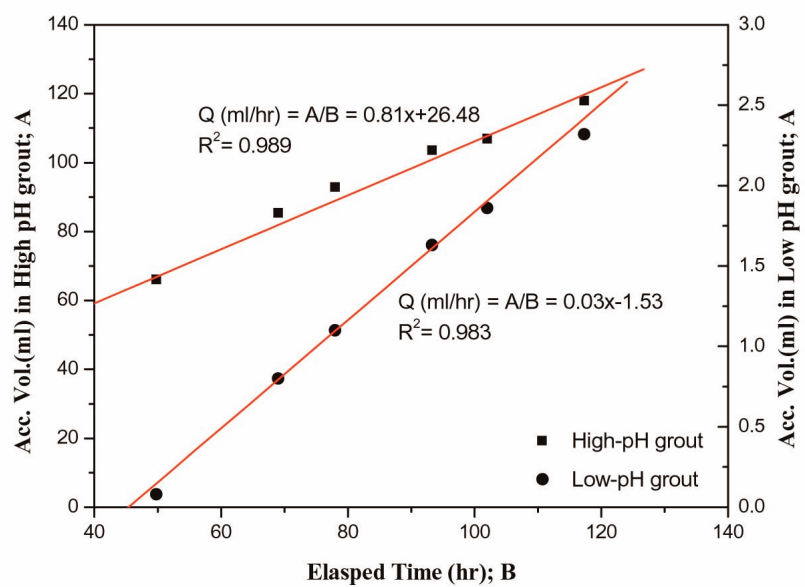

Fig. 8. HyDraulic Conductivity Measured by the Steady-state Flow Method: Cumulative Volume Versus Time Within a Linear Range. $\mathrm{m} / \mathrm{sec}$ ) [29]. On the other hand, the hydraulic conductivity of HP is $1.06 \times 10^{-11} \mathrm{~m} / \mathrm{sec}$. The hydraulic conductivity values of LP are about two orders of magnitude lower than those obtained for HP.

The decrease in hydraulic conductivity is considered to be a consequence of the decrease in pore size and the reduction of the connected capillary pore space (microfiller) due to the addition of SF [29, 30]. Onofrei et al. (1992) showed that under conditions of $\mathrm{w} / \mathrm{b}$ ranging from 0.4 to $0.8, \mathrm{SF}$-added grout decreases the apparent hydraulic conductivity $(\mathrm{K})$ to approximately $10^{-15} \mathrm{~m} / \mathrm{sec}$, which is only slightly influenced by $\mathrm{w} / \mathrm{b}$; the value for high-strength $\mathrm{SF}$ grout is 2 to 3 orders of magnitude lower than that typically observed for intact granite [29]. However, SF simultaneously acts to reduce the hydraulic conductivity, which enhances the long-term durability of the grout and increases the demands in $\mathrm{w} / \mathrm{b}$, which generally results in low density and leads to a greater possibility of water ingress and shrinkage. Therefore, for field application to verify the effects of LP, it is necessary to decide on the optimized $\mathrm{w} / \mathrm{b}$ based on the long-term concerns of stability, strength development, workability, and injection ability, along with a lowering of $\mathrm{pH}$.

\section{CONCLUSIONS}

The material properties of low-pH cement grout, such as $\mathrm{pH}$, uniaxial compressive strength, dynamic modulus, and hydraulic conductivity were experimentally investigated through laboratory tests. Based on the test results, the main findings are the following:

-At the early stage of $\mathrm{pH}$ measurement, both high- and low-pH cement grouts show a $\mathrm{pH}$ of around 12.9. While the $\mathrm{pH}$ of the high-pH (i.e., conventional) cement grout gets close to a constant of 12.5 after about 30 days, low-pH cement grouts have $\mathrm{pH}$ levels that continuously decrease and finally converge within a curing age of 180 days. In this process, the $\mathrm{pH}$ requirement $(<\mathrm{pH} 11)$ is obtained after 130 days.

-Compared to the uniaxial compressive strengths of high-pH cement grout, those of low-pH cement grouts are lower due to the larger content of SF than that generally used in high-strength concrete; however, the levels still satisfy the strength requirements for low-pH cement grouts used for radioactive repositories $(\geq 4 \mathrm{MPa}$ at $28 \mathrm{~d}$ ).

-The elastic wave velocities of high-pH cement grout are faster than those of low-pH cement grouts. Meanwhile, the damping ratios of dry low-pH cement grouts are about two times greater than that of saturated low-pH cement grouts. The dynamic shear modulus of low-pH cement grout changes from $0.9 \mathrm{GPa}$ under dry conditions to $1.6 \mathrm{GPa}$ under saturated conditions.

-The measured hydraulic conductivity of low-pH cement 
grouts is approximately $10^{-13} \mathrm{~m} / \mathrm{sec}$ and is about two orders of magnitude lower than that of high-pH cement grout.

Although the fresh mixture characteristics of low-pH cement grout are relatively well known, there is little information on long-term cement grout degradation with regard to durability and to ensure a watertight repository structure, especially for over 100 years. For the field application of low-pH cement grout in a radioactive repository, therefore, it is necessary to further study the material degradation of cement grout, considering issues of chemical stability and leaching, and using numerical modeling in the prediction of service-life.

\section{ACKNOWLEDGEMENTS}

This work was supported by the Nuclear Research \& Development Program of the Korea Science and Engineering Foundation (KOSEF) through a grant funded by the Korean government (MEST) (Grant code: M207 03040004-08M0304-00410).

\section{REFERENCES}

[1] OECD Nuclear Energy Agency (NEA), Nuclear Energy Outlook 2008, OECD (2008).

[2] D. Bodansky, Nuclear energy: Principles, practices and prospects. 2nd ed. New York, American Institute of Physics (1996).

[ 3 ] A. Kronlöf, "Injection grout for deep repositories-Low $\mathrm{pH}$ cementitious grout for larger fractures: Testing technical performance of materials," Posiva Working Report 200445. Finland, Posiva Oy (2005).

[ 4 ] U. Sievänen, P. Raivio, U. Vuorinen, J. Hansen, J. Norokallio, P. Syrjänen, "Optimization of technical properties of lowpH cementitious injection grout: Laboratory tests and pilot field test 3," Posiva Working Report 2006-85, Finland, Posiva Oy (2006).

[5] A. Bodén and U. Sievänen, "Low-pH injection grout for deep repositories," Posiva Working Report 2005-24, Finland, Posiva Oy (2006).

[6] M. Mihara, K. Iriya, A. Neyama and M. Ito, "Experimental and modeling studies on the interaction between cement paste with silica fume and distilled water," Radioactive Wasted Research, 3, 2, p.71-80 (1997).

[ 7 ] K. Orantie and H. Kuosa, "Durability 2007 injection grout investigation-Background description," Posiva Working Report 2008-54, Finland, Posiva Oy (2008).

[8] H. P. Torbjörn, L. Björn and V. Carsten, "Selective stabilization of deep core drilled boreholes using low-pH cement," Proceedings of the 2nd Low-pH workshop, ESDRED, Madrid, Spain, June, 15-16, 2005.

[9] S. David and B. Steven, "Low pH cements," SKI Report 2007:32, Sweden, SKI (2007).

[10] C. L. Page and O. Vennesland, "Pore solution composition and chloride binding capacity of silica fume cement paste," Mat. and Strut., 16, 91, p.19-25 (1983).

[11] K. Byfors, C. M. Hansson, and J. Tritthart, "Pore solution expression as a method to determine the influence of mineral additives on chloride binding," Cement and Concrete Res., 16, 5, p.760-770 (1986).

[12] J. Duchesne and M. A. Bérubé, "Evaluation of the validity of the pore solution expression method from hardened cement pastes and mortars," Cement and Concrete Res., 24, 3, p.456-462 (1983).

[13] H. Ana, L. G. Jose, C. A. Maria, F. L. Luis and A. Carmen, "Testing methodology for $\mathrm{pH}$ determination of cementitious materials: Application to low $\mathrm{pH}$ binders for use in HLNWR," Proceedings of the 2nd Low-pH workshop, ESDRED, Madrid, Spain, June, 15-16, 2005.

[14] V. Räsänen and V. Penttala, "The pH measurement of concrete and smoothing mortar using a concrete powder suspension," Cement and Concrete Res., 34, p.813-820 (2004).

[15] ASTM C 109, "Standard test method for compressive strength of hydraulic cement mortars," American Society for Testing and Materials (2009).

[16] N. Swamy and G. Rigby, "Dynamic properties of hardened paste, mortar and concrete," Materials and structures, 4, 1, p.13-40 (1971).

[17] KS F2437, “Testing method for dynamic modulus of elasticity, rigidity and dynamic Poisson's ratio of concrete specimens by resonance vibration," (2008).

[18] ASTM C 215, "Standard test method for fundamental transverse longitudinal and torsional resonant frequencies of concrete specimens," American Society for Testing and Materials (2008).

[19] CRD-C 163-92, "Test method for water permeability of concrete using triaxial cell," U.S. Army Corps of Engineers (1992).

[20] Korea Concrete Institute, Concrete Engineering. 2nd ed. Seoul: KCI (2007).

[21] J. M. Soler, "Thermodynamic description of the solubility of CSH gels in hydrated Portland cement_Literature review," Posiva Working Report 2007-88, Finland, Posiva Oy (2007).

[22] K. O. Kjellsen and R. J. Detwiler, "Reaction kinetics of Portland cement mortars hydrated at different temperatures," Cement and Concrete Res., 22, p.112-120 (1992).

[23] M. Vuorio and J. Hansen, "Long-term safety and durability related studies on low-pH grouting materials," Proceedings of the 3rd Low-pH workshop, ESDRED, Paris, France, June, 15-16, 2007.

[24] S. Bhanja and B. Sengupta, "Optimum silica fume content and its mode of action on concrete," ACI Materials Journal, 100, 5, p.407-412 (2003).

[25] prEN206-1, "Concrete-Part 1: Specification, performance, production and conformity," European Standard (2000).

[26] E. Holt, "Durability of low-pH injection grout: A literature survey," Posiva Working Report 2007-57, Finland, Posiva Oy (2007).

[27] J. J. Recalde, "Estimating crack growth in temperature damaged concrete," PhD dissertation, North Carolina State University (2009).

[28] T. Qiu and P. J. Fox, "Hydraulic damping of saturated poroelastic soils during steady-state vibration," $A S C E$ Journal of engineering mechanics, 132, 8, p.859-870 (2006).

[29] M. Onofrei, G. Malcolm, W. Coons and S. Alcorn, "High 
KIM et al., Properties of Low-pH Cement Grout as a Sealing Material for the Geological Disposal of Radioactive Waste

performance cement-based grouts for use in a nuclear waste disposal facility," Waste Materials, 8, p.132-138 (1992).

[30] A. A. Al-Manaseer, M. Onofrei, M. N. Gray and B. Shenton, "The effect of silica fume and water/cement ratio on the hydraulic conductivity of cement-based grout," Proceeding of Scientific Basis for Nuclear Waste Management XIV Symposium, Pittsburgh, U.S., p.443-440 (1991). 